\title{
Prediction of Mortality by High-Sensitivity C-Reactive Protein and Brain Natriuretic Peptide in Patients With Dilated Cardiomyopathy
}

\author{
Chitose Ishikawa, MD; Takayoshi Tsutamoto, MD; Masanori Fujii, MD; \\ Hiroshi Sakai, MD; Toshinari Tanaka, MD; Minoru Horie, MD
}

\begin{abstract}
Background The prognostic role of serum C-reactive protein (CRP) in chronic heart failure (CHF) patients, especially those with nonischemic dilated cardiomyopathy (DCM), remains unknown. In the present study, whether CRP provides prognostic information in DCM patients was evaluated.

Methods and Results Neurohumoral factors and hemodynamics in 84 consecutive DCM patients were measured and these patients were followed up for a mean period of 42 months. During the follow-up period, 23 patients developed cardiac events and 18 patients died of cardiac causes. Using stepwise multivariate Cox proportional hazards regression analyses, log brain natriuretic peptide (BNP) $(\mathrm{p}=0.007)$ and high-sensitivity CRP (hsCRP) $>1 \mathrm{mg} / \mathrm{L}$ ( $\mathrm{p}=0.008$ ) were significant independent predictors of cardiac events. The patients were stratified into 4 groups based on the normal serum concentration of hsCRP $(1 \mathrm{mg} / \mathrm{L})$ and median plasma concentration of BNP $(110 \mathrm{pg} / \mathrm{ml})$. Survival rates were significantly higher in patients with hsCRP $<1 \mathrm{mg} / \mathrm{L}$ and BNP $<110 \mathrm{pg} / \mathrm{ml}$. The hazard ratio of patients with BNP $>110 \mathrm{pg} / \mathrm{ml}$ and hsCRP $>1 \mathrm{mg} / \mathrm{L}$ was 15.8 (95\% confidence interval, 1.9-127.2) compared with those with BNP $<110 \mathrm{pg} / \mathrm{ml}$ and hsCRP $<1 \mathrm{mg} / \mathrm{L}$ for cardiac death.

Conclusions Serum hsCRP level is an independent prognostic predictor in patients with DCM and the combination of hsCRP and BNP may be useful for the management of CHF patients with DCM. (Circ J 2006; 70: $857-863)$
\end{abstract}

Key Words: Brain natriuretic peptide; Dilated cardiomyopathy; High-sensitivity C-reactive protein; Prognosis

$\mathbf{N}$ eurohumoral factors, including proinflamatory cytokines, become activated and play important roles in the pathophysiology of chronic heart failure (CHF), so monitoring these factors can provide prognostic information!-6 Recent studies have suggested that an elevated level of high-sensitivity C-reactive protein (hsCRP) is a useful prognostic predictor in CHF?,8 Most patients with CHF have atherothrombotic disease, such as coronary artery disease and hypertensive heart disease, so a high level of hsCRP indicates a risk of vascular death from atherothrombotic disease in CHF patients.

The serum level of hsCRP is elevated in patients with CHF regardless of the cause.-13 To our knowledge, there have not been any clear reports about the prognostic value of hsCRP in CHF patients with nonischemic dilated cardiomyopathy. We have reported that the plasma brain natriuretic peptide (BNP) level is a potent prognostic predictor of biochemical markers in patients with $\mathrm{CHF}^{3}, 4$ Currently, the plasma BNP level is considered an important prognostic predictor not only in patients with CHF and acute coronary syndrome ${ }^{14}$ but also in the general population ${ }^{15}$ suggesting that plasma BNP is a sensitive and specific biochemical marker of ventricular wall stress. We have also reported

(Received February 9, 2006; revised manuscript received March 31, 2006; accepted April 18, 2006)

Department of Cardiovascular and Respiratory Medicine, Shiga University of Medical Science, Otsu, Japan

Mailing address: Takayoshi Tsutamoto, MD, Department of Cardiovascular and Respiratory Medicine, Shiga University of Medical Science, Tsukinowa, Seta, Otsu 520-2192, Japan. E-mail: tutamoto @ belle.shiga-med.ac.jp that plasma interleukin (IL)-6, one of the key cytokines, is an independent prognostic indicator and an additional risk factor for mortality in CHF patients $16,17 \mathrm{C}$-reactive protein (CRP) is mainly produced in the liver through stimulation from cytokines such as IL- 6 . Therefore, the serum CRP level correlates with that of IL-6, but the prognostic role of the serum CRP level compared with the IL-6 level in CHF patients, especially those with dilated cardiomyopathy (DCM), remains unknown. Moreover, CRP itself causes endothelial dysfunction and contributes deterioration of CHF with DCM ${ }^{18-20}$ Therefore, in the present study, we evaluated whether the serum hsCRP level provides prognostic information in addition to that obtained from standard clinical, hemodynamic and biochemical variables such as BNP and IL-6, which have previously been associated with high mortality in CHF patients with DCM.

\section{Methods}

\section{Patient Population}

The study population consisted of 84 consecutive DCM patients who were admitted between December 1998 and October 2004. The diagnosis of DCM was based on patient history, physical examination, electrocardiography, chest radiology, echocardiography, left ventriculography and coronary angiography. All patients were free of hypertension, ischemic heart disease, valvular heart disease, congenital malformations of the heart or vessels, and intrinsic pulmonary, renal, inflammatory or metabolic diseases. Endomyocardial biopsies were obtained to rule out secondary cardiomyopathies caused by viral or other infectious myo- 
Table 1 Clinical and Hemodynamic Characteristics of 84 Patients With DCM

\begin{tabular}{lc}
\hline \hline Age (years) & $55.9 \pm 1.5$ \\
M/F & $68 / 16$ \\
NYHA classification & \\
$I$ & $12(14.3 \%)$ \\
II & $39(46.4 \%)$ \\
III & $30(35.7 \%)$ \\
IV & $3(3.6 \%)$ \\
LVEF $(\%)$ & $33.8 \pm 1.0$ \\
PCWP $\left(\right.$ mmHg $\left.^{-2}\right)$ & $11.0 \pm 0.8$ \\
CI $\left(\right.$ Lin $\left.^{-1} \cdot \mathrm{m}^{-2}\right)$ & $3.08 \pm 0.51$ \\
Medications at entry & \\
Furosemide & $64(76.2 \%)$ \\
Spironolactone & $56(66.7 \%)$ \\
ACEI or ARB & $62(73.8 \%)$ \\
Digitalis & $44(52.4 \%)$ \\
B -blockers & $27(32.1 \%)$ \\
Statin & $10(11.9 \%)$ \\
Aspirin & $30(35.7 \%)$ \\
\hline
\end{tabular}

DCM, dilated cardiomyopathy; NYHA, New York Heart Association; LVEF left ventricular ejection fraction; PCWP, pulmonary capillary wedge pressure; CI, cardiac index; ACEI, angiotensin converting enzyme inhibitors; $A R B$, angiotensin receptor blocker.

carditis, sarcoidosis, amyloidosis or other metabolic heart disease. Patients with secondary DCM and those with infectious disease were excluded from the study. Patients with renal failure (serum creatinine $>2 \mathrm{mg} / \mathrm{dl}$ ) were also excluded. Cardiac catheterization was performed after improvement of the CHF symptoms. The investigation conformed to the principles outlined in the Declaration of Helsinki. Written informed consent was given by all patients before participating in the present study, and the protocol was approved by the institutional Human Investigations Committee.

\section{Study Protocol}

All patients were premedicated with an oral dose of diazepam $(5 \mathrm{mg}$ ) and rested in bed for at least $20 \mathrm{~min}$. Right-sided cardiac catheterization was performed using a Swan-Ganz catheter. Blood samples for measuring plasma levels of IL-6, BNP, norepinephrine (NE) and endothelin (ET)-1 and serum hsCRP were collected from the aortic root. Left ventriculography was performed using contrast medium after obtaining hemodynamic measurements and blood samples. All patients were followed for more than 12 months (mean follow-up 42 months).

\section{Measurements of Cytokines and Neurohumoral Factors}

Blood for measurement of the plasma levels of BNP, IL-6 and ET-1 was transferred to a chilled tube containing EDTA $(1 \mathrm{mg} / \mathrm{ml})$ and aprotinin (500 kallikrein inactivator units $/ \mathrm{ml})$. NE was transferred to a chilled tube containing EDTA $(1 \mathrm{mg} / \mathrm{ml})$, then centrifuged at $3,000 \mathrm{rpm}$ for $15 \mathrm{~min}$ at $4{ }^{\circ} \mathrm{C}$, and the plasma thus obtained was stored at $-30^{\circ} \mathrm{C}$ until assay. Plasma BNP concentrations were measured with a specific immunoradiometric assay kit for human BNP (Shionogi, Osaka, Japan) as previously reported? IL-6 measurement was performed using a commercially available immunoassay kit (Quantikine HS, R\&D Systems, Minneapolis, MN, USA) as previously reported 16 ET-1 levels were measured by radioimmunoassay as previously reported21 Plasma NE concentrations were measured by high-performance liquid chromatography.

Blood for measurement of the serum level of hsCRP was transferred to a chilled tube, then centrifuged at 3,000 rpm for $15 \mathrm{~min}$ at $4^{\circ} \mathrm{C}$, and the serum thus obtained was stored at $-30^{\circ} \mathrm{C}$ until assay. Serum hsCRP was measured by a sensitive nephelometric assay (Behring Diagnostics, Marburg, Germany).

\section{Statistical Analysis}

All results are expressed as the mean \pm SEM. Univariate analysis was performed using Student's t-test. Categorical data were compared against a chi-square distribution. The prognostic value of the variables was tested in a Cox proportional hazards regression analysis. A Kaplan-Meier analysis was performed on the cumulative rates of survival in patients with CHF stratified into 4 groups based on median plasma levels of BNP and normal concentration of hsCRP, and the differences between the survival curves were analyzed using a log-rank test. To determine whether the serum hsCRP concentration seen in our CHF patients was an independent prognostic factor or only reflected the importance of other factors, 13 variables were entered into a Cox proportional hazard analysis. Linear regression analysis was used to determine the relationship between continuous variables. BNP, hsCRP and IL-6 were highly skewed and therefore logarithmically transformed in all analyses. A value of $\mathrm{p}<0.05$ was considered significant.

\section{Results}

Patient Characteristics and Hemodynamic Data (Table 1)

The subjects were 68 men and 16 women ranging in age from 16 to 80 years old (mean: 55 years). Twelve patients were classified according to the standards of the New York Heart Association (NYHA) as functional class I, 39 as class II, 30 as class III and 3 as class IV. At entry into the present study, 64 patients were treated with furosemide, 56 with spironolactone, 62 with angiotensin-converting enzyme inhibitors (ACEI) or angiotensin-receptor blockers (ARB), 44 with digitalis, 27 with $\beta$-blockers, 10 with statin and 30 with aspirin. After 6 months follow up, 71 patients were receiving ACEI or ARB (89.8\%), and 57 patients were receiving $\beta$-blockers $(72.1 \%)$.

\section{Plasma Concentrations of Neurohumoral Factors and Cytokines in Patients With DCM}

In the present study, we defined NYHA functional class I or II as mild CHF, III or IV as severe CHF. In CHF patients with DCM, plasma levels of BNP, NE, ET-1, serum hsCRP and pulmonary capillary wedge pressure (PCWP) were increased with the severity of CHF (Fig 1). In the present study, cardiac events were defined as cardiac death or hospitalization for worsening heart failure. In patients with cardiac events, plasma BNP, NE, serum hsCRP and PCWP were higher and the left ventricular ejection fraction (LVEF) was lower than those in patients without cardiac events. There were no significant differences of plasma IL-6 and ET-1 levels between the patients with cardiac events and those without cardiac events (Fig 2).

\section{Comparisons Between Serum hsCRP and Hemodynamic Date or Neurohumoral Factors}

Serum log hsCRP concentration significantly correlated with plasma log IL-6 $(\mathrm{R}=0.455, \mathrm{p}<0.0001)$. However, there was no relationship between serum log hsCRP and plasma $\log$ BNP. There was no relationship between log hsCRP and LVEF (Fig 3). According to stepwise multivariate 


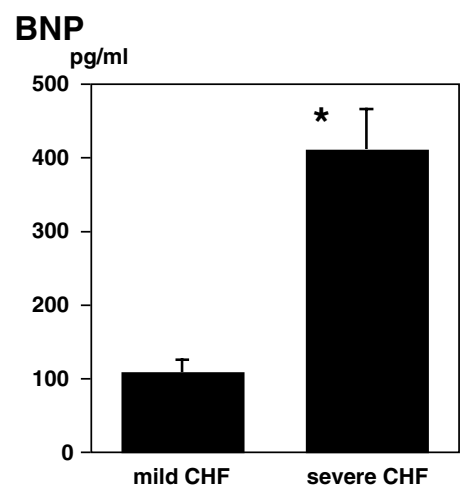

ET-1
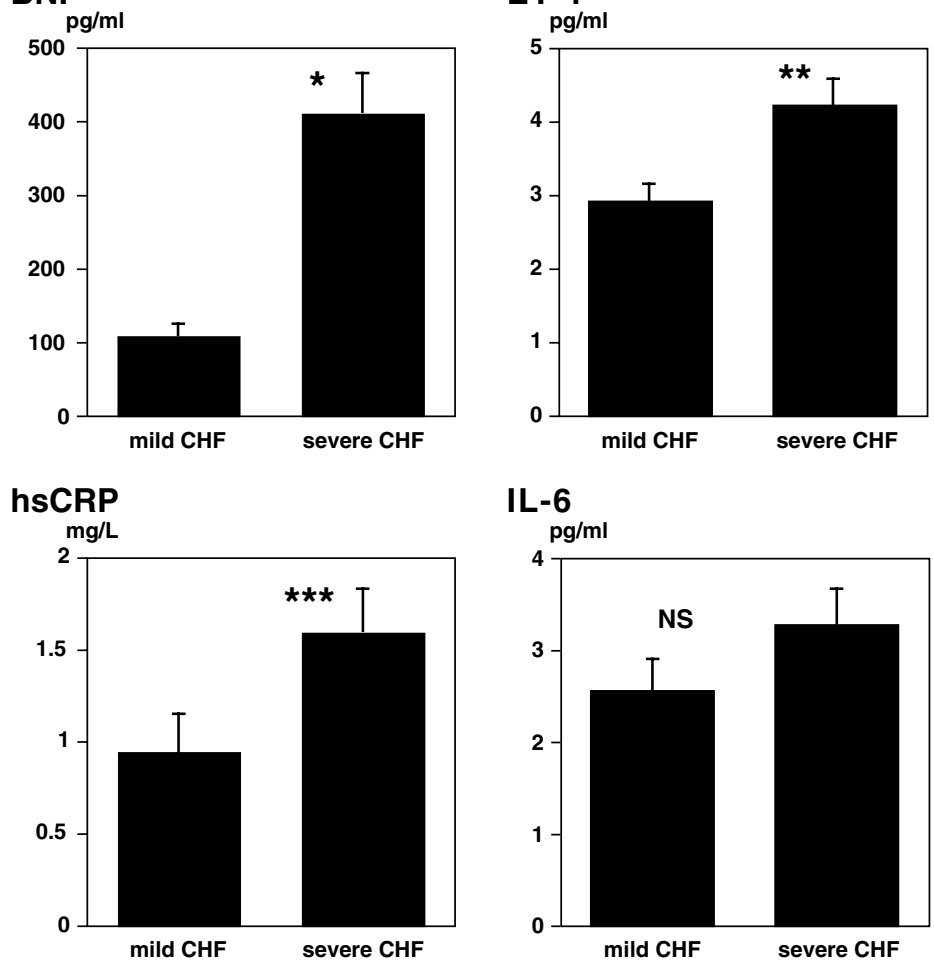

BNP
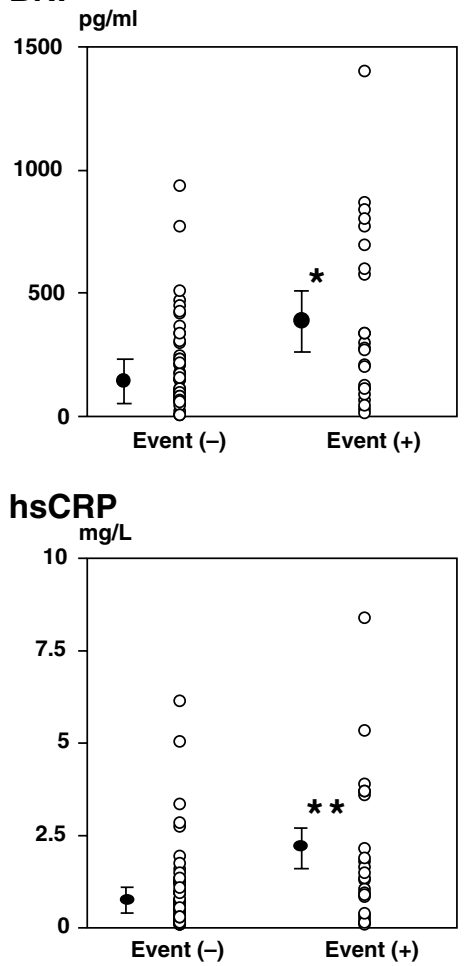

IL-6

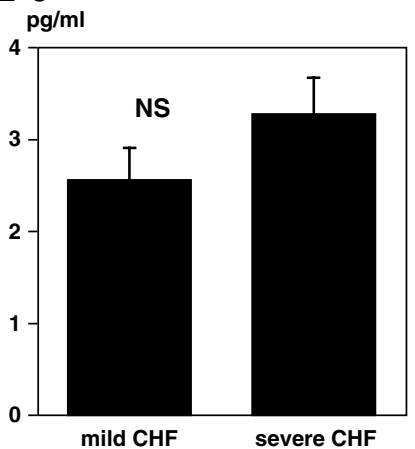

ET-1

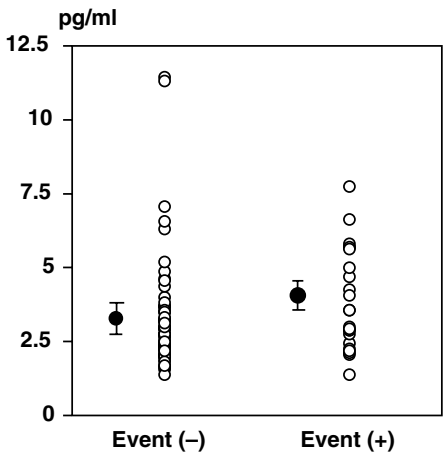

IL-6

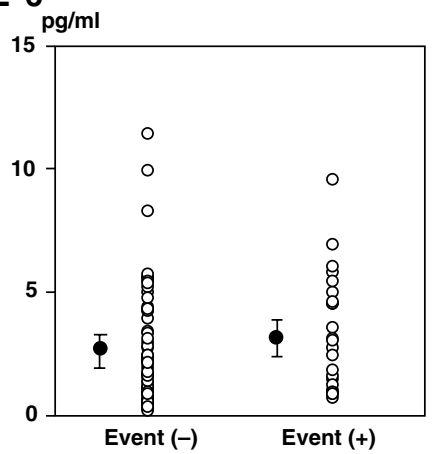

Fig 1. Plasma levels of brain natriuretic peptide (BNP), endothelin (ET)-1 and interleukin (IL)-6, serum level of high-sensitivity C-reactive protein (hsCRP) in mild and severe chronic heart failure (CHF) patients with dilated cardiomyopathy. Mild $\mathrm{CHF}=\mathrm{New}$ York Heart Association (NYHA) functional class I-II; severe $\mathrm{CHF}=\mathrm{NYHA}$ functional class III-IV. $* \mathrm{p}<0.0001$ vs the value in patients with mild CHF, $* * \mathrm{p}<0.005$ vs the value in patients with mild $\mathrm{CHF}, * * * \mathrm{p}<0.05$ vs the value in patients with mild CHF.
Fig 2. Plasma levels of brain natriuretic peptide (BNP), endothelin (ET)-1 and interleukin (IL)-6, serum level of high-sensitivity C-reactive protein (hsCRP) in chronic heart failure (CHF) patients with dilated cardiomyopathy. Event $(-)=$ patients without cardiac events during the follow-up period, event $(+)=$ patients with cardiac events during follow-up period. $* \mathrm{p}<0.001$ vs the value in patients without cardiac events; $* * \mathrm{p}<0.005$ vs the value in patients without cardiac events. analyses between neurohumoral factors and hemodynamics, only log IL-6 showed an independent and significant positive relationship with log hsCRP (Table 2).

\section{Univariate and Multivariate Predictors of Cardiac Events}

During the long-term follow-up period, 23 patients had cardiac events and 18 patients died of cardiac causes. Thir- teen clinical, neurohumoral and hemodynamic variables were analyzed using univariate and stepwise multivariate Cox proportional hazards regression analyses. Using univariate analyses, NYHA class, LVEF, PCWP, plasma NE, $\log \mathrm{BNP}$ and serum hsCRP $>1 \mathrm{mg} / \mathrm{L}$ were significant predictors of cardiac events. According to stepwise multivariate analyses, $\log \mathrm{BNP}(\mathrm{p}=0.007)$ and hsCRP $>1 \mathrm{mg} / \mathrm{L}(\mathrm{p}=$ 
$\log$ IL-6
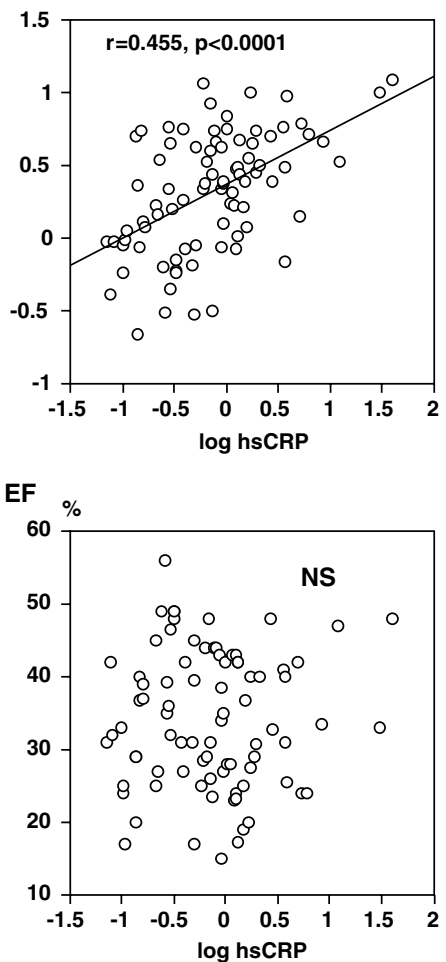

$\log B N P$

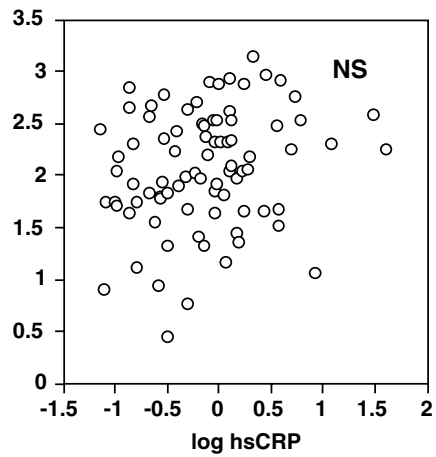

PCWP

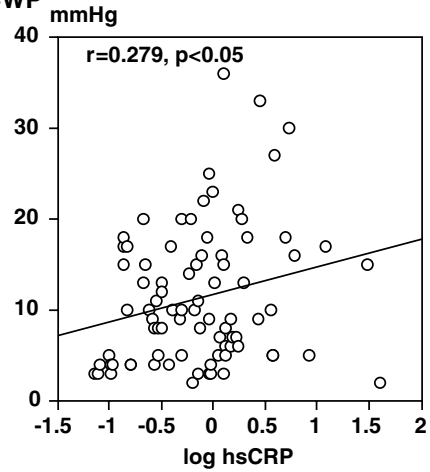

Fig 3. Relationship between log high-sensitivity C-reactive protein (hSCRP) and other neurohumoral factors or hemodynamics. IL, interleukin; BNP, brain natriuretic peptide; EF, ejection fraction; PCWP, pulmonary capillary wedge pressure.

Table 2 Univariate and Multivariate Linear Models of Serum log hsCRP in 84 Patients With DCM

\begin{tabular}{lcccc}
\hline \hline & $\begin{array}{c}\text { Univariate } \\
\text { correlation coefficient }\end{array}$ & $p$ value & $\begin{array}{c}\text { Multivariate } \\
\text { coefficient }(\mathrm{SE})\end{array}$ & $p$ value \\
\hline Age $($ years $)$ & 0.110 & 0.3201 & & \\
NYHA classification & 0.293 & 0.0069 & & \\
$\log \mathrm{BNP}(\mathrm{pg} / \mathrm{ml})$ & 0.200 & 0.0682 & $22.928(0.126)$ & $<0.0001$ \\
$\log \mathrm{IL}-6(\mathrm{pg} / \mathrm{ml})$ & 0.455 & $<0.0001$ & \\
NE $(\mathrm{pg} / \mathrm{ml})$ & 0.268 & 0.0137 & \\
ET-1 $(\mathrm{pg} / \mathrm{ml})$ & 0.064 & 0.5606 & \\
LVEF $(\%)$ & -0.054 & 0.6269 & \\
PCWP $\left(\mathrm{mmHg}^{-1}\right)$ & 0.279 & 0.0101 & \\
CI $\left(\mathrm{L} \cdot \mathrm{min}^{-1} \cdot \mathrm{m}^{-2}\right)$ & -0.006 & 0.9597 & \\
\hline
\end{tabular}

hsCRP, high-sensitivity C-reactive protein; BNP, brain natriuretic peptide; IL, interleukin; NE, norepinephrine; ET, endothelin. See Table 1 for other abbreviations.

Table 3 Univariate and Multivariative Predictors of Cardiac Events in 84 Patients With DCM

\begin{tabular}{|c|c|c|c|c|}
\hline & $\begin{array}{l}\text { Univariate } \\
\text { chi-square }\end{array}$ & $p$ value & $\begin{array}{l}\text { Multivariate } \\
\text { chi-square }\end{array}$ & $p$ value \\
\hline Age (years) & 0.515 & 0.473 & 1.164 & $N S$ \\
\hline Men (1)/women (0) & 0.83 & 0.362 & 0.902 & NS \\
\hline NYHA classification & 10.23 & 0.001 & 0.656 & $N S$ \\
\hline$H b(m g / d l)$ & 0.917 & 0.338 & 0.181 & $N S$ \\
\hline Serum Cre $(m g / d l)$ & 0.123 & 0.726 & 0.037 & $N S$ \\
\hline $\log B N P(p g / m l)$ & 10.12 & 0.001 & 7.11 & 0.007 \\
\hline$h s C R P>1 \mathrm{mg} / L(1) /<1 \mathrm{mg} / \mathrm{L}(0)$ & 11.73 & $<0.001$ & 6.974 & 0.008 \\
\hline $\log I L-6(\mathrm{pg} / \mathrm{ml})$ & 2.265 & 0.132 & 0.016 & $N S$ \\
\hline$N E(p g / m l)$ & 6.992 & 0.008 & 1.717 & $N S$ \\
\hline ET-1 $(\mathrm{pg} / \mathrm{ml})$ & 1.984 & 0.159 & 0.028 & $N S$ \\
\hline $\operatorname{LVEF}(\%)$ & 3.933 & 0.047 & 1.661 & $N S$ \\
\hline$P C W P(\mathrm{mmHg})$ & 7.5 & 0.006 & 0.155 & $N S$ \\
\hline$C I\left(L \cdot \mathrm{min}^{-1} \cdot \mathrm{m}^{-2}\right)$ & 0.9 & 0.342 & 0.686 & $N S$ \\
\hline
\end{tabular}

Hb, hemoglobin; Cre, creatinine.

See Tables 1,2 for other abbreviations. 
Table 4 Univariate and Multivariative Predictors of Mortality in 84 Patients With DCM

\begin{tabular}{|c|c|c|c|c|}
\hline & $\begin{array}{l}\text { Univariate } \\
\text { chi-square }\end{array}$ & $p$ value & $\begin{array}{c}\text { Multivariate } \\
\text { chi-square }\end{array}$ & $p$ value \\
\hline Age (years) & 1.185 & 0.276 & 2.113 & $N S$ \\
\hline Men (1)/women (0) & 0.124 & 0.724 & 0.086 & $N S$ \\
\hline NYHA classification & 4.193 & 0.04 & 0.141 & NS \\
\hline$H b(m g / d l)$ & 1.294 & 0.255 & 0.187 & NS \\
\hline Serum Cre $(m g / d l)$ & 0.002 & 0.964 & 0.061 & $N S$ \\
\hline $\log B N P(p g / m l)$ & 8.642 & 0.003 & 6.125 & 0.013 \\
\hline$h s C R P>1 \mathrm{mg} / \mathrm{L}(1) /<1 \mathrm{mg} / \mathrm{L}(0)$ & 9.23 & 0.002 & 5.324 & 0.021 \\
\hline $\log I L-6(p g / m l)$ & 1.58 & 0.208 & 0.01 & $N S$ \\
\hline$N E(p g / m l)$ & 1.594 & 0.206 & 0.027 & $N S$ \\
\hline ET-1 $(\mathrm{pg} / \mathrm{ml})$ & 0.109 & 0.741 & 0.797 & NS \\
\hline $\operatorname{LVEF}(\%)$ & 3.152 & 0.075 & 1.097 & $N S$ \\
\hline$P C W P(m m H g)$ & 2.674 & 0.102 & 0.605 & $N S$ \\
\hline$C I\left(L \cdot \mathrm{min}^{-1} \cdot \mathrm{m}^{-2}\right)$ & 0.642 & 0.423 & 0.48 & $N S$ \\
\hline
\end{tabular}

See Tables 1-3 for abbreviations.

A

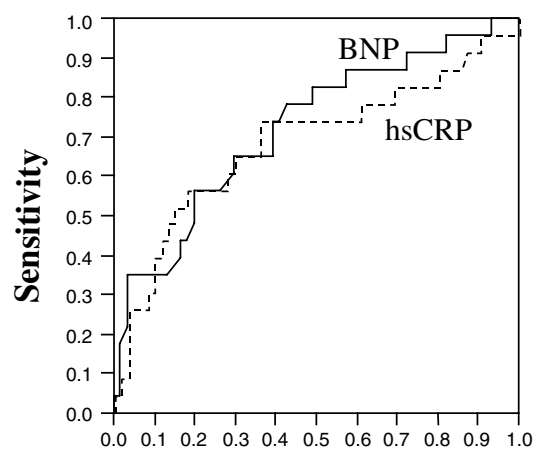

1-Specificity
B

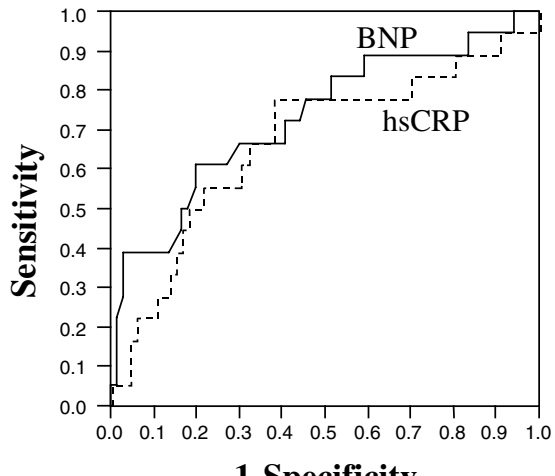

1-Specificity
Fig 4. Plot showing receiver operating characteristic curves for prediction of cardiac events (A) and mortality (B) for plasma level of brain natriuretic peptide (BNP) and serum level of high-sensitivity C-reactive protein (hsCRP).
A

Kaplan-Meier Cardiac Event Curvrs

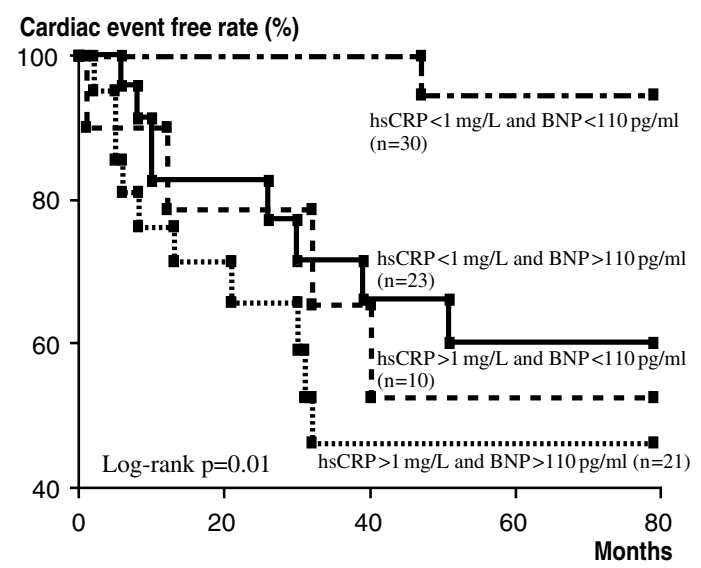

B

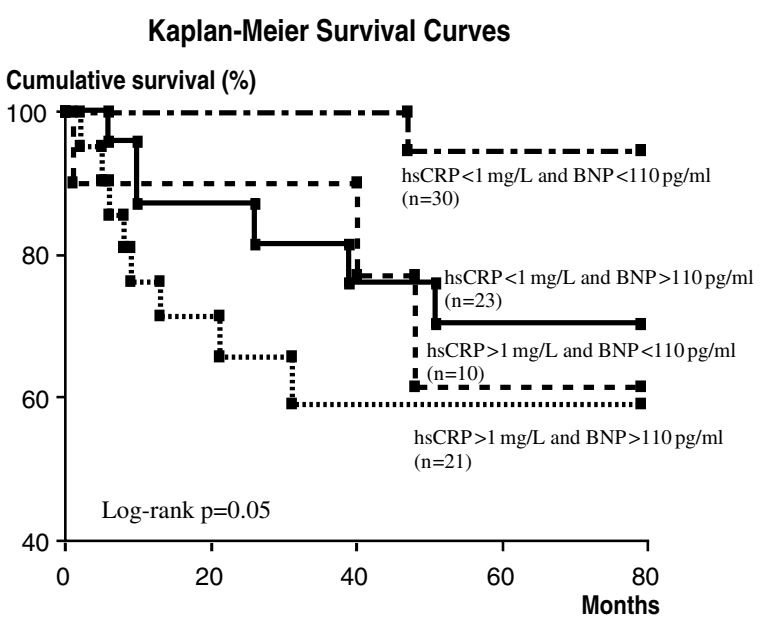

Fig 5. Kaplan-Meier cardiac event curves (A) and survival curves (B) for patients with dilated cardiomyopathy stratified into 4 groups based on normal serum concentration of high-sensitivity C-reactive protein (hsCRP) and median plasma concentration of brain natriuretic peptide (BNP).

0.008) were significant independent predictors of cardiac events (Table 3). The relative risk ratio of $\log$ BNP was 3.9 (95\% confidence interval (CI), 1.4-9.6), and that of hsCRP $>1 \mathrm{mg} / \mathrm{L}$ was $3.4(95 \% \mathrm{CI}, 1.4-8.1)$. Log BNP $(\mathrm{p}=0.013)$ and hsCRP $>1 \mathrm{mg} / \mathrm{L}(\mathrm{p}=0.021)$ were significant independent predictors of mortality (Table4). The relative risk ratio of $\log$ BNP was $4.4(95 \% \mathrm{CI}, 1.3-12.2)$, and that of hsCRP $>1 \mathrm{mg} / \mathrm{L}$ was 3.3 (95\% CI, 1.2-9.0).

\section{Kaplan-Meier Lifetime Analysis}

Patients were stratified into 4 groups based on normal serum concentration of hsCRP $(1 \mathrm{mg} / \mathrm{L})$ and median plasma 
concentration of BNP $(110 \mathrm{pg} / \mathrm{ml})$, and cumulative survival curves were constructed by Kaplan-Meier event methods. The normal hsCRP level is defined as a low-risk group by both the American Heart Association and the Centers for Disease Control and Prevention.22 From receiver operating characteristic curve analysis, hsCRP $>1 \mathrm{mg} / \mathrm{L}$ had a sensitivity of $60.8 \%$ and a specificity of $72.2 \%$, and BNP $>110 \mathrm{pg} / \mathrm{ml}$ had a sensitivity of $78.2 \%$ and a specificity of $57.4 \%$ for cardiac events. hsCRP $>1 \mathrm{mg} / \mathrm{L}$ had a sensitivity of $61.1 \%$ and a specificity of $68.2 \%$, and BNP $>110 \mathrm{pg} / \mathrm{ml}$ had a sensitivity of $77.7 \%$ and a specificity of $54.6 \%$ for mortality (Fig 4). Survival rates, as evaluated using Kaplan-Meier event analysis, were significantly higher in patients with serum hsCRP concentration $<1 \mathrm{mg} / \mathrm{L}$ and BNP $<110 \mathrm{pg} / \mathrm{ml}$ than in patents with hsCRP $>1 \mathrm{mg} / \mathrm{L}$ and BNP $>110 \mathrm{pg} / \mathrm{ml}$ (Fig 5). The hazard ratio of patients with BNP $>110 \mathrm{pg} / \mathrm{ml}$ and hsCRP $>1 \mathrm{mg} / \mathrm{L}$ was $15.8(95 \% \mathrm{CI}$, 1.9-127.2) compared to those with BNP $<110 \mathrm{pg} / \mathrm{ml}$ and hsCRP $<1 \mathrm{mg} / \mathrm{L}$ for cardiac death.

\section{Discussion}

The prognostic value of hsCRP has been established in patients with atherothrombotic disease ${ }^{23,24}$ and in the present study, we tested its role in CHF patients with nonischemic DCM. There was no significant correlation between serum hsCRP level and plasma BNP concentration, a possible marker of hemodynamic overload. However, both hsCRP $>1 \mathrm{mg} / \mathrm{L}$ and BNP were independent prognostic predictors on measurement of hemodynamics and plasma levels of NE, ET-1, and IL-6. Moreover, the hazard ratio for cardiac death in patients with BNP $>110 \mathrm{pg} / \mathrm{ml}$ and hsCRP $>1 \mathrm{mg} / \mathrm{L}$ was 15.8 compared with that of those with BNP $<110 \mathrm{pg} / \mathrm{ml}$ and hsCRP $<1 \mathrm{mg} / \mathrm{L}$, suggesting that the combination of measurements of hsCRP and BNP is useful for the management of CHF caused by DCM.

\section{Why is hsCRP an Independent Prognostic Predictor in Patients With DCM?}

The exact reason for the significant prognostic role of hsCRP in CHF patients with nonischemic DCM remains unknown. Several possibilities are postulated: (1) a high level of hsCRP may reflect an activated immune response involving the myocardium; or (2) CRP itself may cause endothelial dysfunction, as well as being a potential prognostic predictor, thereby causing deterioration of CHF. Expressions of the proinflammatory cytokine tumor necrosis factora and IL-6 have been described in patients with CHF, in both the plasma and in the myocardium, $5,16,17,25,26$ and these cytokines stimulate the production of CRP mainly produced by hepatocytes. Recently, CRP has been found in other tissues, such as atherosclerotic plaque and human coronary artery smooth muscle cells. ${ }^{27}$ Therefore, a high level of hsCRP may reflect an activated immune response in patients with DCM.

CRP is not only a biomarker of inflammation but also a mediator of endothelial dysfunction via stimulation of IL-6, increased ET- $1^{25}$ and decreased NO production.19,20 Previous study has shown that systemic inflammation may contribute to endothelial dysfunction 28 Several recent studies demonstrated that endothelial dysfunction influences the pathogenesis and prognosis of CHF 99,30 Therefore, CRP itself causes endothelial dysfunction, a potential prognostic predictor, and thereby causes deterioration of CHF caused by DCM.

\section{Comparison of hsCRP, IL-6 and BNP as Predictors of $\mathrm{CHF}$}

We have reported that the plasma IL-6 level is an independent prognostic indicator, as well as an additional risk factor for mortality in CHF patients. ${ }^{16,17}$ In the present study, hsCRP was a stronger predictor than IL-6, partly because IL-6 has a short half-life. In contrast, CRP has a serum half-life of $18-20 \mathrm{~h}$. Furthermore, the assay for hsCRP has been standardized across many commercial platforms, whereas those for other cytokines remain poorly standardized, and methodological issues limit their use despite consistent population-based data.

Both CRP and BNP were reported as important prognostic markers of heart failure in a study of a communitybased elderly population? ${ }^{1}$ In the present study, we demonstrated for the first time that both BNP and hsCRP, which can be measured in standard clinical laboratories, are independent predictors of prognosis in CHF patients. The finding that hsCRP is more useful than IL-6 is good news for clinical practice, because the measurement of hsCRP is universally standardized and costs less than that of IL-6.

\section{Study Limitations}

We evaluated hsCRP and other neurohumoral factors using only one point sampling when patient conditions were relatively stable. We could not observe the time course of neurohumoral factors after treatment for CHF. Further studies of the prognostic role of hsCRP before and after standard therapy for CHF are needed.

The present study is also limited by its modest sample size. Larger studies are needed to confirm whether the hsCRP level itself is a useful prognostic marker for CHF with DCM.

\section{Conclusions}

hsCRP is a useful prognostic marker that is independent of hemodynamics and BNP, and the combination of hsCRP and BNP may be useful in the management of CHF patients with DCM.

\section{Acknowledgments}

We wish to thank Ms Akiko Miyagawa for excellent technical assistance. We also thank Mr Daniel Mrozek for assistance in preparing the manuscript.

\section{References}

1. Cohn JN, Levine TB, Olivari MT, Garberg V, Lura D, Francis GS, et al. Plasma norepinephrine as a guide to prognosis in patients with chronic congestive heart failure. N Engl J Med 1984; 311: 819-823.

2. Packer M. Neurohumoral interactions and adaptations in congestive heart failure. Circulation 1988; 77: 721-730.

3. Tsutamoto T, Wada A, Maeda K, Hisanaga T, Maeda Y, Fukai D, et al. Attenuation of compensation of endogenous cardiac natriuretic peptide system in chronic heart failure: Prognostic role of plasma brain natriuretic peptide concentration in patients with chronic symptomatic left ventricular dysfunction. Circulation 1997; 96: 509-516.

4. Maeda K, Tsutamoto T, Wada A, Hisanaga T, Kinoshita M. Plasma brain natriuretic peptide as a biochemical marker of high left ventricular end-diastolic pressure in patients with symptomatic left ventricular dysfunction. Am Heart J 1998; 135: 825-832.

5. Levine B, Kalman J, Mayer L, Fillit HM, Packer M. Elevated circulating levels of tumor necrosis factor in severe chronic heart failure. N Engl J Med 1990; 323: 236-241.

6. Mann DL, Young JB. Basic mechanisms in congestive heart failure: Recognizing the role of proinflamatory cytokines. Chest 1994; 105: 897-904.

7. Yin WH, Chen JW, Jen HL, Chiang MC, Huang WP, Feng AN, et al. 
Independent prognostic value of elevated high-sensitivity C-reactive protein in chronic heart failure. Am Heart J 2004; 147: 931-938.

8. Alonso-Martinez JL, Llorente-Diez B, Echegaray-Agara M, OlazPreciado F, Urbieta-Echezarreta M, Gonzalez-Arencibia C. C-reactive protein as a predictor of improvement and readmission in heart failure. Eur J Heart Fail 2002; 4: 331 -336.

9. Pye M, Rae AP, Cobbe SM. Study of serum C-reactive protein concentration in cardiac failure. Br Heart J 1990; 63: 228-230.

10. Kaneko K, Kanda T, Yamauchi Y, Hasegawa A, Iwasaki T, Arai M, et al. C-reactive protein in dilated cardiomyopathy. Cardiology 1999; 91: $215-219$

11. Sato Y, Takatsu Y, Kataoka K, Yamada T, Taniguchi R, Sasayama $\mathrm{S}$, et al. Serial circulating concentrations of C-reactive protein, interleukin (IL)-4, and IL-6 in patients with acute left heart decompensation. Clin Cardiol 1999; 22: 811-813.

12. Pietila KO, Harmoinen AP, Jokiniitty J, Pasternack AI. Serum Creactive protein concentration in acute myocardial infarction and its relationship to mortality during 24 months of follow-up in patients under thrombolytic treatment. Eur Heart J 1996; 17: 1345 - 1349.

13. Steele IC, Nugent AM, Maguire S, Hoper M, Campbell G, Halliday MI, et al. Cytokine profile in chronic cardiac failure. Eur J Clin Invest 1996; 26: $1018-1022$.

14. Darber D, Davidson NC, Gillespie N, Choy AM, Lang CC, Shyr Y, et al. Diagnostic value of B-type natriuretic peptide concentrations in patients with acute myocardial infarction. Am J Cardiol 1996; 78: 284-287.

15. McDonagh TA, Cunningham AD, Morrison CE, McMurray JJ, Ford I, Marton JJ, et al. Left ventricular dysfunction, natriuretic peptides, and mortality in an urban population. Heart 2001; 86: 21-26.

16. Tsutamoto T, Hisanaga T, Wada A, Maeda K, Ohnishi M, Fukai D, et al. Interleukin-6 spillover in the peripheral circulation increases with the severity of heart failure, and the high plasma level of interleukin6 is an important prognostic predictor in patients with congestive heart failure. J Am Coll Cardiol 1998; 31: 391-398.

17. Maeda K, Tsutamoto T, Wada A, Mabuchi N, Hayashi M, Tsutsui T, et al. High levels of plasma brain natriuretic peptide and interleukin6 after optimized treatment for heart failure are independent risk factors for morbidity and mortality in patients with congestive heart failure. J Am Coll Cardiol 2000; 36: 1587-1593.

18. Devaraj S, Xu DY, Jialal I. C-reactive protein increases plasminogen activator inhibitor-1 expression and activity in human aortic endothelial cells: Implications for the metabolic syndrome and atherothrombosis. Circulation 2003; 107: 398-404.

19. Verma S, Wang CH, Li SH, Dumont AS, Fedak PW, Badiwala MV, et al. A self-fulfilling prophecy: C-reactive protein attenuates nitric oxide production and inhibits angiogenesis. Circulation 2002; 106: 913-919.

20. Clapp BR, Hirschfield GM, Storry C, Gallimore JR, Stidwill RP Singer M, et al. Inflammation and endothelial function: Direct vascu- lar effects of human C-reactive protein on nitric oxide bioavailability. Circulation 2005; 111: $1530-1536$.

21. Tsutamoto T, Wada A, Maeda Y, Adachi T, Kinoshita M. Relation between endothelin-1 spillover in the lungs and pulmonary vascular resistance in patients with chronic heart failure. J Am Coll Cardiol 1994; 23: 1427-1433.

22. Pearson TA, Mensah GA, Alexander RW, Anderson JL, Cannon RO $3^{\text {rd }}$, Criqui M, et al. Markers of inflammation and cardiovascular disease: Application to clinical and public health practice: A statement for healthcare professionals from the Centers for Disease Control and Prevention and the American Heart Association. Circulation 2003; 107: 499-511.

23. Choi H, Cho DH, Shin HH, Park JB. Association of high sensitivity C-reactive protein with coronary heart disease prediction, but not with carotid atherosclerosis, in patients with hypertension. Circ J 2004; 68: 628-633.

24. Yip HK, Hung WC, Yang CH, Chen YH, Cheng CI, Chen SM, et al. Serum concentration of high-sensitivity C-reactive protein predict progressively obstructive lesions rather than late restenosis in patients with unstable angina undergoing coronary artery stenting. Circ J 2005; 69: $1202-1207$.

25. Verma S, Li SH, Badiwala MV, Weisel RD, Fedak PW, Li RK, et al. Endothelin antagonism and interleukin-6 inhibition attenuate the proatherogenic effects of C-reactive protein. Circulation 2002; 105: $1890-1896$.

26. Tsutamoto T, Wada A, Ohnishi M, Tsutsui T, Ishii C, Ohno K, et al. Transcardiac increase in tumor necrosis factor-a and left ventricular end-diastolic volume in patients with dilated cardiomyopathy. Eur $J$ Heart Fail 2004; 6: $173-180$.

27. Yasojima K, Schwab C, McGeer EG, McGeer PL. Generation of Creactive protein and complement components in atherosclerotic plaques. Am J Pathol 2001; 158: 1039-1051.

28. Vita JA, Keaney JF Jr, Larson MG, Keyes MJ, Massaro JM, Lipinska I, et al. Brachial artery vasodilator function and systemic inflammation in the Framingham Offspring Study. Circulation 2004; 110: 3604-3609.

29. Chong AY, Blann AD, Patel J, Freestone B, Hughes E, Lip GY. Endothelial dysfunction and damage in congestive heart failure: Relation of flow-mediated dilatation to circulating endothelial cells, plasma indexes of endothelial damage, and brain natriuretic peptide. Circulation 2004; 110: 1794-1798.

30. Katz SD, Hryniewicz K, Hriljac I, Balidemaj K, Dimayuga C, Hudaihed A, et al. Vascular endothelial dysfunction and mortality risk in patients with chronic heart failure. Circulation 2005; 111: $310-314$.

31. Kistorp C, Raymond I, Pedersen F, Gustafsson F, Faber J, Hildebrandt P. N-terminal pro-brain natriuretic peptide, $\mathrm{C}$-reactive protein, and urinary albumin levels as predictors of mortality and cardiovascular events in older adults. JAMA 2005; 293: 1609-1616. 